\title{
Determinants of Nutritious Drought Tolerant Maize Adoption and Mineral Fertilizer Application Under Smallholder Farm Conditions in Ghana
}

\author{
Stephen Yeboah ${ }^{1}$, Natson Eyram Amengor ${ }^{1}$, Patricia Oteng-Darko ${ }^{1} \&$ Priscilla Francisco Ribeiro $^{1}$ \\ ${ }^{1}$ CSIR-Crops Research Institute, Kumasi, Ghana \\ Correspondence: Stephen Yeboah, CSIR-Crops Research Institute, P.O. Box 3785, Kumasi, Ghana. E-mail: \\ proyeboah@yahoo.co.uk
}

Received: March 19, 2019

Accepted: May 10, 2019 Online Published: July 15, 2019

doi:10.5539/jas.v11n10p121

URL: https://doi.org/10.5539/jas.v11n10p121

\begin{abstract}
The study sought to examine adoption of nutritious drought tolerant (DT) maize using social science research methods and participatory demonstration trials. The social science study used mixed method approach which combined both qualitative and quantitative methods. A split-plot demonstration trial of three improved maize varieties and a local variety, and two levels of Nitrogen fertilizer were established. The two fertilizer levels were low $\mathrm{N}[\mathrm{LN}]\left(30 \mathrm{~kg} \mathrm{~N} \mathrm{ha}^{-1}\right)$ and high $\mathrm{N}[\mathrm{HN}]\left(90 \mathrm{~kg} \mathrm{~N} \mathrm{ha}^{-1}\right)$. The results of the social science study showed 85\% of men consider early maturity, grain quality and storability in adopting DT maize. Results also revealed that beside earliness and higher yield, taste and easy to harvest influenced women farmer's choice for DT maize varieties. Climatic endurance, increased yield and grain quality showed a positive and statistically significant relationship with adoption of DT maize. On average, HN fertilization increased DT maize grain yields by $41 \%$ compared to the LN fertilization. The improved DT maize varieties had yield advantages ranging from 25 to $43 \%$ over the local variety. From this, DT maize appears to have a potential for its use with $\mathrm{N}$-fertilizer in the fight against food insecurity with improved adoption and utilization in Ghana.
\end{abstract}

Keywords: climate, on-farm, participatory, socio-economics, stress, yield

\section{Introduction}

Small holder farmers who are dominant players in the agriculture system in Ghana are struggling to adapt to climate change (Asante et al., 2014). In addition, arable land and other production resources are limited, and area expansion for food production is not desirable. Lack of technologies to adapt to environmental changes has led to declining agriculture productivity and food insecurity. Evidence of climate change in Ghana includes variability of temperature and rainfall patterns (Antwi, 2013). Investing in agricultural technologies to boost farmers' resilience against weather shocks is a key strategy to reduce negative impacts (Yeboah et al., 2018). In a country like Ghana, with poor or missing markets for insurance and credit and limited off-farm employment opportunities, adoption of agricultural management strategies that reduce production risks is an important option for smallholder farmers (Kassie et al., 2015).

Drought is one of the most important environmental factors constraining maize production in Ghana. Drought tolerant (DT) maize is one potential technology that has the capacity to help smallholders adapt to drought risks. Also, maize has a critical nutritional role to play in addressing the problem of malnutrition in Ghana through biofortification, because it is the most important staple food crop across Ghana. Quality Protein Maize if adopted offers a unique opportunity to impact positively on the nutrition of malnourished people because it may supply as much as $70-73 \%$ of the human protein requirements compared to $46 \%$ for conventional maize (Menkir et al., 2005). Potential therefore exists to address the problem of crop failure due to drought and malnutrition in Ghana through promotion and dissemination of nutritious drought tolerant maize varieties.

Despite the successes of CSIR-Crops Research Institute and its collaborators in the development and release of many maize varieties, its adoption in many maize-producing regions has been limited. The low adoption rate and in some cases, discontinued use of new varieties for maize production could be traced to a complex set of socio-economic factors (Kijima et al., 2011). Exploring the reasons for this is crucial to understand how the technologies can be more successfully developed and disseminated. We examined the adoption of DT maize 
among smallholder farmers in Ghana, focusing on resources allocation and ownership, determinants of DT maize adoption and gender responses.

In agreement with other studies, it was hypothesized that adoption of drought tolerant quality protein maize would allow significant reduction in malnutrition and increase yields in the face of climate variability's. This study therefore focuses on the determinants of adoption of drought tolerant maize in the savannas of Ghana. The study also demonstrated effect of $\mathrm{N}$ fertilization on both improved and unimproved maize varieties in sub-optimal nutrient soils.

\section{Method}

\subsection{Experimental Site}

The study was conducted during the 2018 major and minor growing seasons at the Aframso in EjuraSekydumase and Atebubu-Amantin Municipalities in the savanna zones of Ghana. The study area was selected because of its involvement as a research location in the drought tolerant maize dissemination and adoption drive. The soil ranges from sandy loam or clay and the undulating topography allows for mechanized farming. The study area lies in the transitional zones and has bimodal rainfall ranging between 1,200 mm-1,500 mm (Antwi, 2013). Agriculture is the dominant economic activity and slash and burn is the most prevalent farming practice in the area (Yeboah et al., 2014). This practice exposes the land to erosional activities leading to excessive leaching.

\subsection{Social Research Methods}

This study was conducted with the mixed method approach which combined both qualitative (Focused group discussion and key informant interviews) and quantitative (Survey) methods in exploring the socio-economic factors such as gender, educational level and income that determined dissemination and adoption of DT maize. In relation to sampling, 80 respondents were targeted for this study consisting of 40 men and 40 women. For the focused group discussion, respondents were categorized into two groups namely men and women who have heard of DT maize varieties and adopted one or more and women who have not heard of the DT maize varieties and have not adopted any of them. Four focus groups made up of seven respondents each were therefore interviewed. In addition, 4 key informants were interviewed namely Men's lead farmers, Women's lead farmer, Agricultural Extension Agent for the study area and the lead researcher for DT maize program at CSIR-Crops Research Institute, Ghana. Eight (8) respondents who had not heard of DT maize (4 men and 4 women) were also interviewed. Structured questionnaires were also administered to 20 men and 20 women from the community. Total sample size therefore was 80 respondents.

The dependent variable in this study, Adoption of Drought Tolerant Maize (DTMADOPT) was defined as a binary variable with a value 1 for farmers who cultivate drought tolerant maize and 0 for farmers who do not. The linear probability model which is an acceptable statistical method in establishing determinants of adoption was employed in this study. The linear probability model is therefore stated as follows:

$$
Y=f\left(X_{1}, X_{2}, \ldots X_{n}, U\right)
$$

Where, $Y$ is the adoption of the drought tolerant maize variety and $X$ is the dependent factors that are likely to have an effect on the adoption of drought tolerant maize and $U$ is the error term. $X$ is therefore given as follows: $\mathrm{X}_{1}=$ Respondent Age; $\mathrm{X}_{2}=$ Marital Status; $\mathrm{X}_{3}=$ Residence Status; $\mathrm{X}_{4}=$ Household Size; $\mathrm{X}_{5}=$ Membership of FBO; $\mathrm{X}_{6}=$ Yield; $\mathrm{X}_{7}=$ DTM Income Change; $\mathrm{X}_{8}=$ Climatic Endurance; $\mathrm{X}_{9}=$ Consumption Taste; $\mathrm{X}_{10}=$ Storability; $\mathrm{X}_{11}=$ Grain Quality; $\mathrm{X}_{12}=$ Pest and Disease Resistance; $\mathrm{X}_{13}=$ Easy to Harvest; $\mathrm{X}_{14}=$ Pest and Disease Susceptibility; $\mathrm{X}_{15}=$ Financial Constraint; $\mathrm{X}_{16}=$ Poor Seed Access. 
Table 1. List of variables, labels and propositions

\begin{tabular}{|c|c|c|}
\hline Variables & Labels & Propositions \\
\hline Respondent Age & Respondents' Age & \\
\hline Marital Status & Respondent's Marital Status & $+/-$ \\
\hline Residence Status & Respondents Residential Status & $+/-$ \\
\hline Household Size & Number of people in a household & $+/-$ \\
\hline Membership Of FBO & Membership of a farmer based organization. Yes $=1, \mathrm{No}=0$ & + \\
\hline Yield & Yield from previous season's production & $+/-$ \\
\hline DTM Income Change & Use of drought tolerant maize income & + \\
\hline Climatic Endurance & Does climatic endurance encourage the adoption of drought tolerant maize $?$ Yes $=1$, No $=0$ & + \\
\hline Consumption Taste & Does consumption taste encourage adoption of drought tolerant maize $\mathrm{Yes}=1, \mathrm{No}=0$ & + \\
\hline Storability & Does grain storability encourage the adoption of drought tolerant maize $?$ Yes $=1$, No $=0$ & + \\
\hline Grain Quality & Does grain quality encourage the adoption of drought tolerant maize? $\mathrm{Yes}=1$, No $=0$ & + \\
\hline Pest And Disease Resistance & Does pest and disease resistance encourage the adoption of drought tolerant maize? Yes $=1$, No $=0$ & + \\
\hline Easy Harvest & Does easy harvest encourage the adoption of drought tolerant maize? $\mathrm{Yes}=1, \mathrm{No}=0$ & + \\
\hline Pest And Disease Susceptibility & Is pest and disease susceptibility a constraint to the adoption of drought tolerant maize? Yes $=1$, No $=0$ & - \\
\hline Financial Constraint & Is financial constraint a constraint to the adoption of drought tolerant maize? Yes $=1$, No $=0$ & - \\
\hline Poor Seed Access & Is poor access to seed a constraint to the adoption of drought tolerant maize? Yes $=1$, No $=0$ & - \\
\hline
\end{tabular}

\subsection{On-Farm Demonstration Trials of Maize Varieties Under N Fertilization}

On-farm demonstration trial investigated the effects of $\mathrm{N}$ fertilization on yield of three improved DT maize varieties and a local variety.

\subsubsection{Soil Sampling and Analysis}

Soil samples were collected prior to establishment of the experiments for the determination of physical and chemical properties. The soils samples were collected from three points in each plot using a soil corer at $0-10$ $\mathrm{cm}$, bulked and mixed. The samples were air-dried, ground to $<2 \mathrm{~mm}$, and then analyzed. Soil organic carbon was determined by a modified Walkley-Black wet oxidation method (Nelson \& Sommers, 1984). Total nitrogen content (TN) of the soil was determined using the Kjeldahl digestion and distillation procedure as described by Bremner and Mulvaney (1982). The table below shows the initial soil properties at the study sites.

Table 2. Soil chemical properties of experimental sites

\begin{tabular}{|c|c|c|c|c|}
\hline \multirow{2}{*}{ Soil properties } & \multirow{2}{*}{$\begin{array}{l}\text { Ejura } \\
0-10 \mathrm{~cm}\end{array}$} & \multirow{2}{*}{$\frac{\text { Atebubu }}{0-10 \mathrm{~cm}}$} & \multicolumn{2}{|c|}{ Landon (1991) Interpretation } \\
\hline & & & High & Low \\
\hline Organic C (\%) & 1.36 & 1.13 & $>10.0$ & $<4.0$ \\
\hline Total N (\%) & 0.23 & 0.10 & $>0.5$ & $<0.2$ \\
\hline Ex K (Cmolc/kg) & 0.07 & 0.08 & $>0.6$ & $<0.2$ \\
\hline Av P $(\mathrm{Mg} / \mathrm{kg})$ & 24.22 & 19.31 & $>50.0$ & $<15.0$ \\
\hline
\end{tabular}

Note. Ex: Exchangeable, Av: Available.

\subsection{Experimental Design and Treatments}

Four replications of two nitrogen levels (High nitrogen [HN] and low nitrogen [LN], three improved maize varieties (Abontem, Omankwa, Honampa) and one local variety (farmer variety) were laid out in a split- plot design. The main plot was the maize varieties and sub-plot was nitrogen fertilizer. The two nitrogen fertilizer levels were; low $\mathrm{N}[\mathrm{LN}]\left(30 \mathrm{~kg} \mathrm{~N}^{-1}\right)$ and high $\mathrm{N}[\mathrm{HN}]\left(90 \mathrm{~kg} \mathrm{~N}^{-1}\right)$. The plot sizes were $4 \mathrm{~m} \times 4 \mathrm{~m}$ square meters with I $\mathrm{m}$ spacing. The field, which was fallow over the previous cropping season, was prepared using a tractor- pulled plow and harrowed. The crop was top dressed with $46 \mathrm{~kg} \mathrm{ha}^{-1}$ sulphate of ammonia.

\subsection{Grain and Biomass Yield $\left(\mathrm{kg} \mathrm{ha}^{-1}\right)$}

At physiological maturity, maize plants were hand-harvested from an area of $6.4 \mathrm{~m}^{2}(4 \mathrm{~m} \times 1.6 \mathrm{~m})$ per plot. The above ground biomass and grain yield were determined on dry weight basis by oven-drying at $105^{\circ} \mathrm{C}$ for 45 min and then dried to constant weight at $85{ }^{\circ} \mathrm{C}$. The grains were separated, air-dried, cleaned, weighed and the grain yield per hectare for each treatment was extrapolated. 


\subsection{Data Management}

Data of the social research study was managed using Stata Version 14.2 (quantitative) and Atlas Ti 7 (qualitative) and outputs presented in tables, charts and graphs. Data of the On-Farm demonstration trial was analyzed using the mixed effect of the Statistical Package for the Social Sciences 22.0 (IBM Corporation, Chicago, IL, USA) with the treatment as the fixed effect and the replicate as the random effect. Differences between the means were determined using the Tukey's honestly significant difference test. All statistical analyses used a 5\% probability level $(\mathrm{P}<0.05)$.

\section{Results and Discussion}

\subsection{Technology Transfer, Resource Ownership and Decision Making in Maize Production}

Maize production is a major activity in the study area, therefore issues of technology transfer of improve maize varieties and production technologies are very important in ensuring increased production and income of smallholder farmers. In terms of technology transfer, it was established that Research Institutions collaborated with Agricultural Extension Agents to conduct field trials on improved maize varieties in the study area. As indicated in Figure 1, research institutions were the major source of improved drought tolerant maize varieties and had a two way relationship with the agricultural extension services. Upon receipt of the new varieties and it related improved technologies, the agricultural extension services then upon consultation with the community choose suitable plots for field demonstrations and farmer field schools. It is worth noting that the interactions of the extension services occur more with the men farmers than the women farmers. Information on new improved technologies therefore flows from the researchers through the extension services to the male farmers and then to the female farmers. As indicated in Figure 1, there are instances where project interventions require direct interactions with the various gender groups. A direct link was found between researchers and men and women farmers as well as agricultural extension agents and men and women farmers separately. These occur in the minorities as indicated in Figure 1. Peterman et al. (2014) emphasized that a gender gap is created because the productivity of women is hindered by the socio-cultural barriers that prevents women from having access to productive resources, markets, information, and technologies. The limited access to resources for women farmers who are mainly involve in subsistence food production would ultimately lead to the deterioration of food security situation of rural women and children.

In the case of resource ownership, it was established that resources were mostly owned by men (Figure 1). Land was owned by the men and then transferred to the women upon request. The volume of land requested by the women was subject to the men's assessment of the capacity of the women to be able to cultivate the requested field efficiently. In the event that a woman required land outside the husband's fields, the woman has to discuss with the husband in sought of approval. The husband then leads the woman to acquire the land. These results are in agreement with the finding of Peterman et al. (2011) where they stated that women have limited control when it comes to productive resources. Stockbridge (2007) also explains that because the household food needs are the responsibility of the women, they grow low valued crops meant mostly for home consumption. The constraints faced by women in access to productive resources, could partly be blamed for the underperformance of agricultural sector in many developing countries including Ghana. This is because women represent a crucial resource in agriculture and the rural economy through their multiple roles as farmers, labourers and entrepreneurs. This observation is consistent with the findings of Anríquez (2010) that limited access by women to productive resources is a great hinderance to agricultural growth in developing countries. 


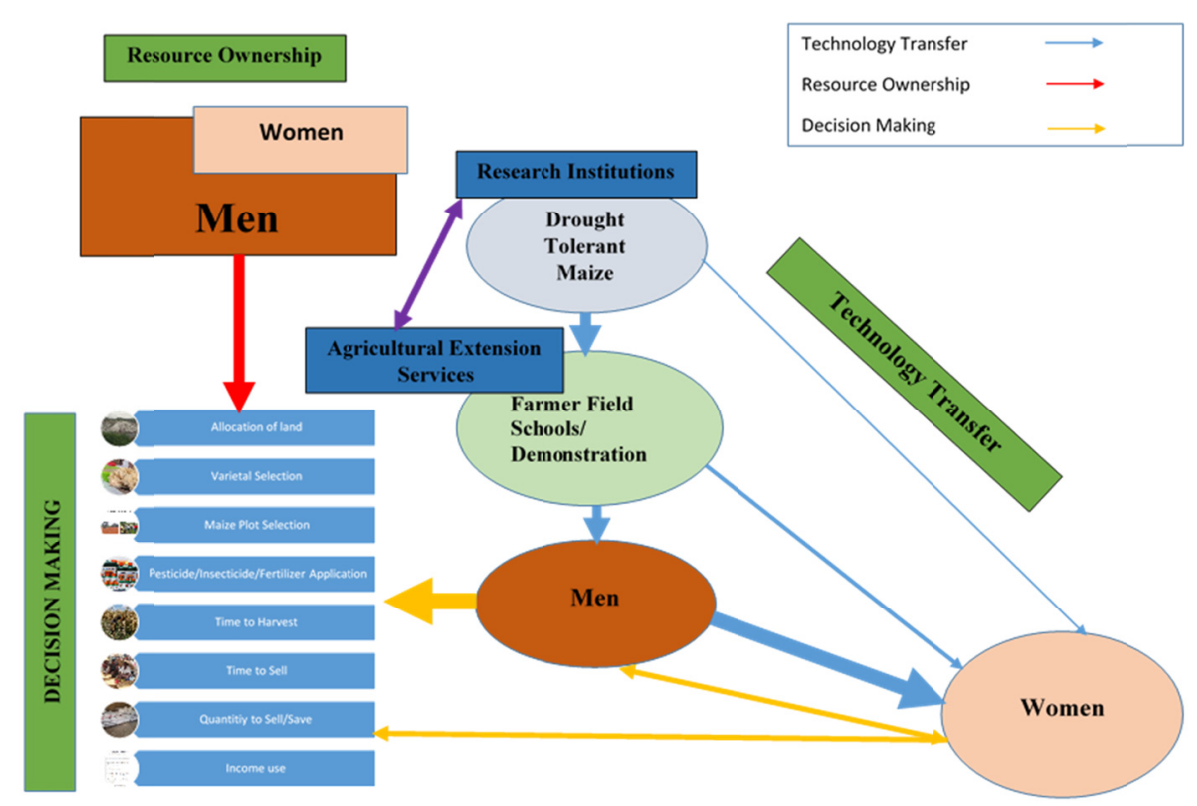

Figure 1. Technology transfer, resource ownership and decision making in drought tolerant maize production Source: Field study, 2018.

\subsection{Awareness and Adoption of Drought Tolerant Maize}

\subsubsection{Perceptions That Promote Adoption of Drought Tolerant Maize}

Farmers have perceptions that affect their adoption of improved maize varieties. A gender analysis of the factors driving the adoption of DT varieties showed some variations. As indicated in Figure 2 and Table 3, the women showed more interest in issues related to Consumption (Taste), Early Maturity, Increased yield and Easy to harvest. However, the men were more interested in Increased yield, Early maturity and Storability. Tolerance to drought was unanimously accepted by both men and women. Considering the results as presented in table 3 , early maturity, consumption (taste), increased yield, grain quality and easy harvesting were the major considerations in the adoption of drought tolerant maize and this confirms the results as obtained from the qualitative study indicated in Figure 2. This result shows that, while tolerance to drought, increased yield and early maturity were common factors that drive the adoption of DT varieties for both men and women farmers, taste and easy to harvest were specific to women farmers, and storability to men farmers. Akudugu et al. (2012) observed different adoption trends of improved maize varieties by men and women farmers in Ghana. The results suggest that while strategies targeted at promoting men farmers adoption of DT varieties should consider storability, increasing uptake of DT varieties by women farmers should focus on consumption (taste) and easy harvesting. 


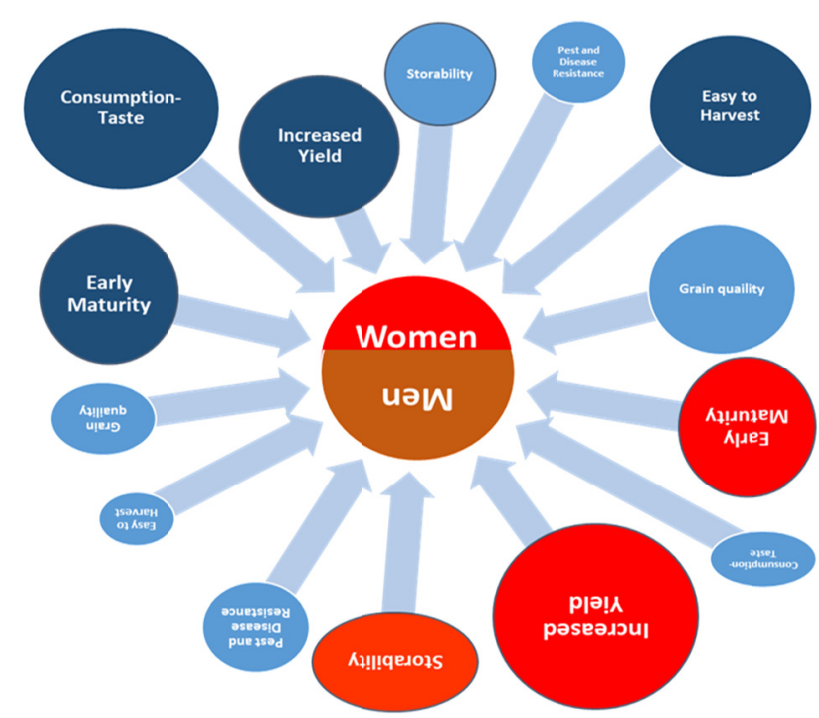

Figure 2. Factors that encourage the adoption of drought tolerant maize varieties

Source: Field study, 2018.

Table 3. Factors that influence adoption of improved varieties

\begin{tabular}{|c|c|c|c|}
\hline Variables & Woman (\%) & Man (\%) & Total $(\%)$ \\
\hline \multicolumn{4}{|c|}{ Early Maturity } \\
\hline No & 16.7 & 6.3 & 11.8 \\
\hline Yes & 83.3 & 93.8 & 88.2 \\
\hline Total & 100.0 & 100.0 & 100.0 \\
\hline \multicolumn{4}{|c|}{ Consumption-Taste } \\
\hline No & 27.8 & 31.3 & 29.4 \\
\hline Yes & 72.2 & 68.8 & 70.6 \\
\hline Total $\ldots . .$. & 100.0 & 100.0 & 100.0 \\
\hline \multicolumn{4}{|c|}{ Increased Yield } \\
\hline No & 38.9 & 12.5 & 26.5 \\
\hline Yes & 61.1 & 87.5 & 73.5 \\
\hline Total & 100.0 & 100.0 & 100.0 \\
\hline \multicolumn{4}{|l|}{ Storability } \\
\hline No & 61.1 & 62.5 & 61.8 \\
\hline Yes & 38.9 & 37.5 & 38.2 \\
\hline Total & 100.0 & 100.0 & 100.0 \\
\hline \multicolumn{4}{|c|}{ Grain Quality } \\
\hline No & 38.9 & 25.0 & 32.4 \\
\hline Yes & 61.1 & 75.0 & 67.6 \\
\hline Total & 100.0 & 100.0 & 100.0 \\
\hline \multicolumn{4}{|c|}{ Resistance To Pest And Diseases } \\
\hline No & 83.3 & 75.0 & 79.4 \\
\hline Yes & 16.7 & 25.0 & 20.6 \\
\hline Total & 100.0 & 100.0 & 100.0 \\
\hline \multicolumn{4}{|c|}{ Easy To Harvest } \\
\hline No & 50.0 & 18.8 & 35.3 \\
\hline Yes & 50.0 & 81.3 & 64.7 \\
\hline Total & 100.0 & 100.0 & 100.0 \\
\hline
\end{tabular}

\subsection{Determinant of Drought Tolerant Maize Adoption}

The linear probability model analytical tool using the ordinary least squares (OLS) method was applied using the linear function because it showed goodness-of-fit F-ratio. Considering a $0.001,0.05$ and 0.10 , levels of significance, Marital status, Residence status, Household Size, Membership of Farmer Based organization, DTM Income Change, Climatic endurance, Grain quality, Pest and Disease Resistance, Pest and Disease Susceptibility, 
Financial constraint, Low storage content and poor handling quality were the factors that determined the adoption of drought tolerant maize in the study area (Table 4). In relation to the socioeconomic factors, there was a negative relationship between marital status and adoption of improve varieties. By implication, unmarried farmers were more likely to adopt a variety as compared to the married farmers. Udensi et al. (2011), studying adoption in some cassava farmers had similar result which emphasize that, though married couples contribute to provide a large labour base for farm work, the numerous household obligations on the woman hinders the adoption of new technologies. Residential status had a positive relationship with the adoption of DT maize as indicated in Table 4. By implication, natives were more likely to adopt drought tolerant maize varieties than settlers. Natives owned and had access to more land than settlers hence could easily commit a portion of their land to new variety trials as compared to settlers who were mostly renting land for production. Household size had a negative relationship with adoption of drought tolerant maize, implying that the greater the household size, the more likely it was for household not to adopt drought tolerant maize. This was consistent with the findings of Idrisa et al. (2012) which concluded that a significantly positive relationship existed between household size and the extent of adoption. Membership of Farmer Based Organization which had become an important phenomenon in the agricultural sector had a positive relationship with the adoption of drought tolerant maize in the study area. Awotide et al. (2016) argued that there was a positive relationship between farmers association with organizations and adoption of improved varieties.

In relation to perceptions, changes that occurred in income as result of growing DT maize had a positive relation with the decision to adoption. It therefore implied that technologies perceived to increase the income of farmers would lead to an increase in the adoption of the variety. Climatic endurance of DT maize had a positive and statistically significant relation with adoption. Varieties that are able to withstand the fluctuating and unreliable weather conditions are more likely to be adopted as compared to those that succumb to the harsh weather conditions. Challa (2013) stated that, uncertainties about climatic factors is likely to make farmers hesitant to adopt the new technology because crop failures makes farmers risk averse hence less likely to try new technologies.

Based on perceived factors that encouraged adoption of drought tolerant maize, grain quality and pest and disease resistance were statistically significant. Grain quality showed a positive relationship with adoption of drought tolerant maize. This implies that good grain quality promotes adoption. Farmers will be less willing to adopt varieties that do not have good grain quality. In relation to perceived factors that constrained adoption of drought tolerant maize, pest and disease susceptibility and financial constraints were statistically significant. Farmers were willing to adopt drought tolerant maize if it was less susceptible to pest and diseases because it had a negative relationship with adoption. In another vain, farmers were less likely to adopt drought tolerant maize when they are heavily constrained financially.

Table 4. Determinant of drought tolerant maize adoption

\begin{tabular}{|c|c|c|c|c|}
\hline Variables & & SE & $\mathrm{t}$ & $\mathrm{P}>|\mathrm{t}|$ \\
\hline Respondent Age & 0.002124 & 0.000510 & 4.16 & 0.150 \\
\hline Marital Status & -0.03393 & 0.003556 & -9.54 & $0.066^{*}$ \\
\hline Residence Status & 0.061534 & 0.005717 & 10.76 & $0.059^{*}$ \\
\hline Household Size & -0.00878 & 0.000631 & -13.91 & $0.046^{* *}$ \\
\hline Membership Of FBO & 0.274582 & 0.005899 & 46.55 & $0.014 * *$ \\
\hline Yield & 0.000577 & 0.000099 & 5.82 & 0.108 \\
\hline DTM Income Change & 0.179174 & 0.006768 & 26.47 & $0.024 * *$ \\
\hline Climatic Endurance & 0.209337 & 0.008736 & 23.96 & $0.027 * *$ \\
\hline Consumption Taste & -0.01501 & 0.006263 & -2.4 & 0.252 \\
\hline Storability & 0.018181 & 0.008733 & 2.08 & 0.285 \\
\hline Grain Quality & 0.234549 & 0.009529 & 24.61 & $0.026 * *$ \\
\hline Pest And Disease Resistance & 0.22008 & 0.009707 & -22.67 & $0.028 * *$ \\
\hline Easy Harvest & 0.056647 & 0.010652 & 5.32 & 0.118 \\
\hline Pest And Disease Susceptibility & -0.207217 & 0.005093 & 40.69 & $0.016 * *$ \\
\hline Financial Constraint & -0.043185 & 0.003100 & 13.93 & $0.046 * *$ \\
\hline Poor Seed Access & -0.02221 & 0.022367 & -0.99 & 0.502 \\
\hline cons & -1.13289 & 0.047242 & -23.98 & $0.027 * *$ \\
\hline Pseudo $\mathrm{R}^{2}=0.240, \mathrm{~F}=0.0001$ & & & & \\
\hline
\end{tabular}




\subsection{On-Farm Demonstration Trial}

\subsubsection{Biomass and Grain Yield of DT and Local Maize Varieties Under Different N Fertilization}

There were no significant treatment interactions $(\mathrm{P}<0.05)$ effect on grain and biomass yield (Tables 5 and 6$)$, but treatment factors independently influenced grain and biomass yield in most cases. The analysis of maize grain yield revealed significant treatment effects within the two locations and seasons (Tables 5 and 6). The average grain yield was slightly higher in the relatively wetter major season $\left(3432 \mathrm{~kg} \mathrm{ha}^{-1}\right)$ than the drier minor season $\left(3141 \mathrm{~kg} \mathrm{ha}^{-1}\right)$. Across seasons and location, the grain and biomass yield of the improved maize varieties were significantly higher than those of the local variety $(\mathrm{P}<0.05$; Tables 5 and 6$)$. Among the improved varieties Abotem DT maize variety consistently had the greatest grain yield across all locations and seasons. Irrespective of environmental and variety, all the plots that received HN fertilizer level increased yields compared to the LN plots. The observed average yield response to the HN fertilization in farmer fields confirm the overall good performance of this technology as has been reported in on-station experiments in northern Benin (Tovihoudji et al., 2017).

Table 5. Biomass yield under different varieties and $\mathrm{N}$ fertilization

\begin{tabular}{|c|c|c|c|c|}
\hline \multirow{2}{*}{ Treatment } & \multicolumn{2}{|c|}{ Major season } & \multicolumn{2}{|c|}{ Minor season } \\
\hline & Ejura & Atebubu & Ejura & Atebubu \\
\hline Abotem & $3361 \mathrm{a}$ & $3258 \mathrm{a}$ & $3275 a$ & $2982 a$ \\
\hline omankwa & $2569 a$ & $3478 \mathrm{a}$ & $3275 a$ & $3432 \mathrm{a}$ \\
\hline Honampa & $2835 \mathrm{ab}$ & $3175 a$ & $3058 \mathrm{a}$ & $2917 \mathrm{a}$ \\
\hline Local variety & $1761 \mathrm{c}$ & $2257 b$ & $2161 b$ & $2068 b$ \\
\hline$P$-value & 0.006 & 0.09 & 0.048 & 0.029 \\
\hline \multicolumn{5}{|c|}{ Sources of variation } \\
\hline Nitrogen $(\mathrm{N})$ & ns & $*$ & ns & ns \\
\hline Variety (V) & $* *$ & ns & $*$ & $*$ \\
\hline $\mathrm{N} \times \mathrm{V}$ & ns & ns & ns & ns \\
\hline
\end{tabular}

Note. $*$, ** indicate significant difference at $\mathrm{P}<0.05, \mathrm{P}<0.01$, respectively. n.s. indicate no significance difference at $\mathrm{P}<0.05$.

Table 6. Grain yield under different varieties and $\mathrm{N}$ fertilization

\begin{tabular}{|c|c|c|c|c|}
\hline \multirow{2}{*}{ Treatment } & \multicolumn{2}{|c|}{ Major season } & \multicolumn{2}{|c|}{ Minor season } \\
\hline & Ejura & Atebubu & Ejura & Atebubu \\
\hline Abotem & $3158 \mathrm{ab}$ & $3135 \mathrm{ab}$ & $3286 a$ & $2898 \mathrm{ab}$ \\
\hline omankwa & $3738 \mathrm{a}$ & $3725 a$ & $3598 \mathrm{a}$ & $3591 \mathrm{a}$ \\
\hline Honampa & $2863 b$ & $2883 \mathrm{ab}$ & $3146 a$ & $2567 \mathrm{ab}$ \\
\hline Local variety & $2032 c$ & $2332 b$ & $2102 b$ & $1901 b$ \\
\hline P-Value & 0.011 & 0.082 & 0.045 & 0.001 \\
\hline \multicolumn{5}{|c|}{ Sources of variation } \\
\hline Nitrogen & $*$ & ns & $*$ & ns \\
\hline Variety & $*$ & ns & $*$ & $* *$ \\
\hline $\mathrm{N} \times \mathrm{V}$ & $\mathrm{ns}$ & ns & ns & $\mathrm{ns}$ \\
\hline
\end{tabular}

Note. $*$, ** indicate significant difference at $\mathrm{P}<0.05, \mathrm{P}<0.01$, respectively. n.s. indicate no significance difference at $\mathrm{P}<0.05$.

\section{Conclusion and Policy Implication}

Weather extremes, especially recurrent droughts threaten agricultural productivity and nutritional food security in Ghana whose population largely depends on agriculture. Drought tolerant maize with an added advantage of high protein content is one promising technology to minimize the impact of droughts and malnutrition. Examining determinants of adoption of this promising technology is very critical. In this study, we find marital status, residential status, household size, membership of farmer based organization, perceived changes to income, 
climatic endurance, grain quality, pest and disease resistance and financial constraints as critical factors that influence adoption. Results also showed positive correlation between the likelihood of adoption of DT maize and climatic endurance, grain quality and earliness. Drought tolerant maize also had higher biomass and grain yield compared to the local check. There was higher preference for improved varieties than unimproved ones. Promotions of technologies that are perceived by farmers as climate-smart based on their experience are likely to receive high adoption rates and make an impact on household livelihood. Agricultural extension messages should therefore emphasize drought tolerant maize seed as a key component in the climate smart Agriculture (CSA) campaign, with extension and promotion messages on the significance of DT maize under drought conditions. The government should make deliberate efforts to distribute more DT maize seed varieties in areas prone to drought shocks, and consider increasing seed subsidy in those areas.

\section{References}

Akudugu, M., Guo, E., \& Dadzie, S. (2012). Adoption of modern agricultural production technologies by farm households in Ghana: What factors Influence their decisions? Journal of Biology, Agriculture and Healthcare, 2(3), 12-20.

Anríquez, G. (2010). Demystifying the Agricultural Feminization Myth and the Gender Burden. Background paper prepared for The State of Food and Agriculture 2011.

Antwi-Agyei, P., Dougill, A. J., Fraser, E. D. G., \& Stringer, L. C. (2013). Characterising the nature of household vulnerability to climate variability: Empirical evidence from two regions of Ghana. Environment Development and Sustainability, 15(4), 903-926. https://doi.org/10.1007/s10668-012-9418-9

Asante, F. A., \& Amuakwa-Mensah, F. (2014). Climate change and variability in Ghana: Stocktaking. Climate, 3(1), 78-99. https://doi.org/10.3390/cli3010078

Awotide, B. A., Karimov, A. A., \& Diagne, A. (2016). Agricultural technology adoption, commercialization and smallholder rice farmers' welfare in rural Nigeria. Agriculture and Food Economics, 4(1), 3. https://doi.org/ 10.1186/s40100-016-0047-8

Bremner, J. M., \& Mulvaney, C. S. (1982). Total nitrogen. In A. L. Page, R. H. Miller, \& D. R. Keeney (Eds.), Methods of soil analysis. Part 2. Chemical and microbiological properties (pp. 593-624). American Society of Agronomy and Soil Science Society of America, Madison Wisconsin Inc.

Challa, M. (2013). Determining factors and impacts of modern agricultural technology adoption in West Wollega. Environment and Development Economics, 496-504.

Idrisa, Y., Ogunbameru, B., \& Madukwe, M. (2012). Logit and Tobit analyses of the determinants of likelihood of adoption and extent of adoption of improved soybean seed in Borno State, Nigeria. Greener Journal Agriculture Science, 2, 37-45. https://doi.org/10.15580/GJAS.2013.3.1231

Kassie, M., Teklewold, H., Marenya, P., Jaleta, M., \& Erenstein, O. (2015). Production risks and food security under alternative technology choices in Malawi: Application of a multinomial endogenous switching regression. Journal of Agriculture and Economics, 66(3). https://doi.org/10.1111/1477-9552.12099

Kijima, Y., Otsuka, K., \& Sserunkuuma, D. (2011). An inquiry into constraints on a green revolution in sub-Saharan Africa: The case of NERICA rice in Uganda. World Dev, 39(1), 77-86. https://doi.org/10.1016/ j.worlddev.2010.06.010

Menkir, A., Kling, J. G., Badu-Apraku, B., \& Ingelbrecht, I. (2005). Molecular marker-based genetic diversity assessment of Striga-resistant maize inbred lines. Theoretical and Applied Genetics, 110, 1145-1153. https://doi.org/10.1007/s00122-005-1946-3

Nelson, D. W., \& Sommers, L. W. (1982). Total carbon, organic carbon and organic matter. In A. L. Page, R. H. Miller, \& D. R. Keeney (Eds.), Methods of Soil Analysis. Part 2. Chemical and Microbiological Properties, Agronomy Monograph (2nd ed., pp. 301-312). American Society of Agronomy, Soil Science Society of America: Madison, WI, USA.

Peterman, A., Behrman, J. A., \& Quisumbing, A. R. (2014). A review of empirical evidence on gender differences in nonland agricultural inputs, technology, and services in developing countries. Gender in Agriculture, 145-186. https://doi.org/10.1007/978-94-017-8616-4_7

Peterman, A., Quisumbing, A., Behrman, J., \& Nkonya, E. (2011). Understanding the complexities surrounding gender differences in agricultural productivity in Nigeria and Uganda. Journal of Development Studies, 47(10), 1482-1509. https://doi.org/10.1080/00220388.2010.536222 
Stockbridge, M. (2007). Agricultural trade policy in developing countries during take-off. Oxfam Policy and Practice: Agriculture, Food and Land, 7(2), 136-196. https://doi.org/10.3362/9780855986544.000

Tovihoudji, P. G., Akponikpè, P. B. I., Agbossou, E. K., Bertin, P., \& Bielders, C. L. (2017). Fertilizer microdosing enhances maize yields but may exacerbate nutrient mining in maize cropping systems in northern Benin. Field Crop Research, 213, 130-142. https://doi.org/10.1016/j.fcr.2017.08.003

Udensi, U., Tarawali, G., Favour, E., Asumugha, G., Ezedinma, C., Okoye, B., \& Dixon, A. (2011). Adoption of selected improved cassava varieties among smallholder farmers in South-Eastern Nigeria. Journal of Food, Agriculture and Environment, 9(1), 329-335.

Yeboah, S., Lamptey, S., Cai, L., \& Song, M. (2018). Short-term Effects of Biochar Amendment on Greenhouse Gas Emissions from rainfed agricultural soils of the semi-arid Loess Plateau Region. Agronomy, 8(74), 1-12. https://doi.org/10.3390/agronomy8050074

Yeboah, S., Owusu Danquah, E., Ennin, S. A., Oteng-Darko, P., \& Asumadu, H. (2014). On-farm evaluation of maize varieties and their yield determining factors in Ghana. World Research Journal of Agronomy, 3(2), 096-101.

\section{Copyrights}

Copyright for this article is retained by the author(s), with first publication rights granted to the journal.

This is an open-access article distributed under the terms and conditions of the Creative Commons Attribution license (http://creativecommons.org/licenses/by/4.0/). 